\title{
Intramural Esophageal Hematoma with Herpes Esophagitis
}

\author{
Kiyoshi Takemoto and Kazuaki Atagi
}

Key words: Intramural esophageal hematoma, herpes esophagitis, extracorporeal membrane oxygenation

\author{
(Intern Med Advance Publication) \\ (DOI: 10.2169/internalmedicine.8284-21)
}
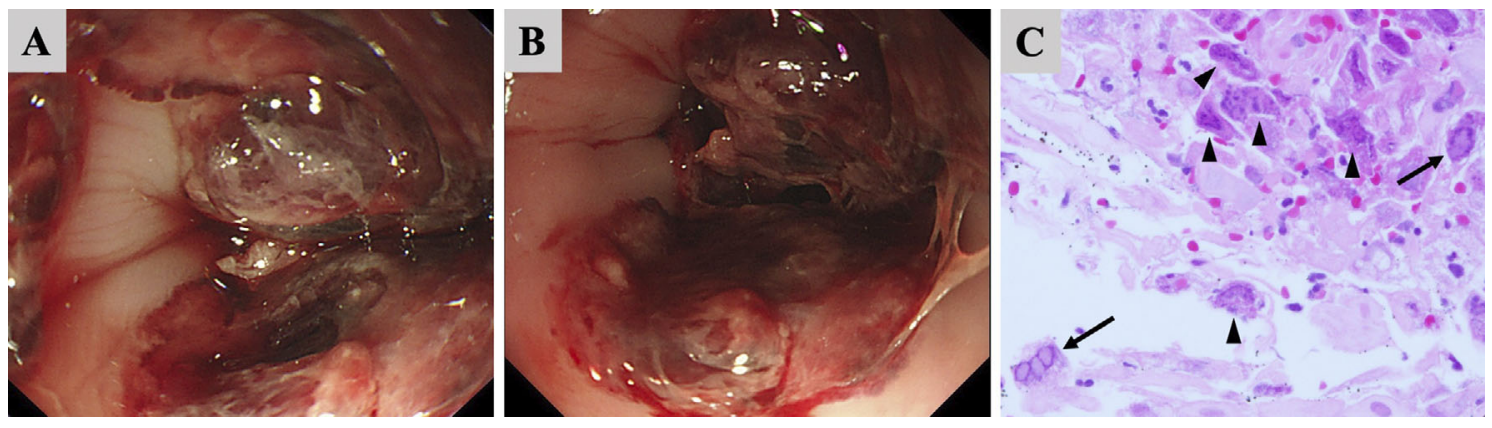

Picture.

A 46-year-old healthy man was diagnosed with rapidly progressive interstitial lung disease associated with positive anti-MDA-5 antibody. He was treated with mechanical ventilation and veno-venous extracorporeal membrane oxygenation (ECMO) for severe hypoxia. Pulse methylprednisolone was administered, followed by prednisolone in combination with tacrolimus and cyclophosphamide. Due to an inadequate response to these drugs, rituximab and tofacitinib were administered in sequence. However, massive hematemesis was observed on day 29. Esophagogastroduodenoscopy revealed mucosal swelling with intramucosal hematoma in the lower esophagus (Picture A, B). A histological examination of a biopsy specimen confirmed herpes esophagitis with hemorrhagic necrosis based on ballooning degeneration of cells (Picture C, arrow) and multinucleated giant cells (Picture $\mathrm{C}$, arrowhead). The degenerated cells were negative for cytomegalovirus (CMV) but positive for herpes simplex virus (HSV) on immunostaining. Unfortunately, due to the uncontrolled gastrointestinal bleeding and worsening respiratory failure caused by intractable interstitial lung disease, he died before the histological diagnosis could be confirmed. We had not anticipated this rare esophageal hemorrhaging at all, so we were unable to test for HSV $\operatorname{IgM}$ or $\operatorname{IgG}$ antibod- ies or conduct DNA polymerase chain reaction and could not administer any antiviral drugs for herpes infection. Although ganciclovir had been administered following this gastrointestinal bleeding, a blood test for CMV antigenemia was negative. Follow-up esophagogastroduodenoscopy was not performed because his general condition had worsened. Although herpes esophagitis is a common infectious esophagitis in the immunocompromised (1), the present case suggests the rare complication of ECMO-related gastrointestinal bleeding with multiple immunosuppressive drugs.

The authors state that they have no Conflict of Interest (COI).

\section{Reference}

1. Hoversten P, Kamboj AK, Wu TT, Katzka DA. Variations in the clinical course of patients with herpes simplex virus esophagitis based on immunocompetence and presence of underlying esophageal disease. Dig Dis Sci 64: 1893-1900, 2019.

The Internal Medicine is an Open Access journal distributed under the Creative Commons Attribution-NonCommercial-NoDerivatives 4.0 International License. To view the details of this license, please visit (https://creativecommons.org/licenses/ by-nc-nd/4.0/). 